\title{
Possibilities of use of waste sulfur for the production of technical concrete
}

\author{
Eukasz Grabowski ${ }^{1, *}$, Maciej Gliniak ${ }^{2}$, and Daria Polek $^{1}$ \\ ${ }^{1}$ AGH University of Science and Technology, Faculty of Mining and Geoengineering, Department of Environmental Engineering and \\ Mineral Processing, Mickiewicza 30 Av., 30-059 Krakow, Poland \\ ${ }^{2}$ University of Agriculture in Krakow, Department of Technical Infrastructure and Ecoenergetics, Institute of Agriculture Engineering \\ and Informatics, Faculty of Production and Power Engineering, Mickiewicza 21 Av., 30-120 Krakow, Poland
}

\begin{abstract}
The article presents the results of research that focused on the selected physical properties of sulphur waste stabilized in concrete. The influence of replacing part of the cement on the physical properties of concrete was studied in the article. The concrete mixtures was modified by pure waste sulphur in amounts of 10,20 and $30 \mathrm{wt} \%$ of the cement. The results show that using sulphur admixture can reduce concrete absorptivity and make concrete more watertight.
\end{abstract}

\section{Introduction}

The growing demand of the construction industry for specialized technical concretes contributes to the increasing emissions of carbon dioxide to the atmosphere. One way to reduce the scale of this phenomenon is to use in the concrete production process selected groups of industrial waste. The most commonly used additives are dust from coal burning and biomass burning [1] and used car tires [2-3].

Because of the increasing requirements for chemical resistance of concrete, many years of work on the addition of polymers improving their resistance to corrosion and mechanical strength have been underway. Waste sulfur is one example of a substance that easily polymerizes and improves the properties of technical concretes. The melting point of the sulfur is about $110{ }^{\circ} \mathrm{C}$, flowing $150-400{ }^{\circ} \mathrm{C}$ and boiling above $400{ }^{\circ} \mathrm{C}$. Thanks to these properties, it is easy to carry out the polymerization of waste by changing its alotropic variation and molecular weight [4-7].

The most popular method of sulfur polymerisation is boiling with water, calcium hydroxide and precipitation with chloride acid. The secondary known method of polymerisation is hydrolysis of sulfur admixture by alcohol solutions. The resulting substances are widely used in the ceramic, electrical and chemical industries as an insulating material. The use of sulfur polymers in technical concrete also improves its mechanical properties, such as strength about 45-50 $\mathrm{MPa}$ by compression. Also known are bacterial deterioration properties of bacteria and sunlight of sulfur concretes [47.

\footnotetext{
* Corresponding author: lukgrabo@agh.edu.pl
}

\section{Materials and methods}

The sulfur concrete consists of the waste sulfur and Portland cement CEM I 42.5 R [8] (from Cement Ozarow SA). The granular sulfur $(99.9 \%)$ was bought from refinery in Poland. The aggregates were natural sand and gravel with the granulation according to the ASTM D 3515 [9].

To obtain the sulfur cement, the different percentages of elemental sulfur have been mixed in a mechanical stirrer in sand bath. Then the mixture was heated to 150 ${ }^{\circ} \mathrm{C}$ and flurried for a 1 hour. Simultaneously the aggregates had been heated to $105^{\circ} \mathrm{C}$ in laboratory dryer. Afterward the filler was added to the cement and then mixed. Next step was adding mixture of the aggregates and blending. The final product was concrete that was casted in the molds that were heated to $150{ }^{\circ} \mathrm{C}$ at the end vibration was done on a vibration table.

Table 1. Composition of the concrete mixes (weight per $\mathrm{m}^{3}$ of concrete, $\mathrm{kg}$ ).

\begin{tabular}{|c|c|c|c|c|c|}
\hline Reference & Cement & Sulphur & Water & Sand & Gravel \\
\hline 0 & 352 & 0 & 176 & 676 & 1205 \\
\hline 10 & 316.8 & 35.2 & 176 & 676 & 1205 \\
\hline 20 & 281.6 & 70.4 & 176 & 676 & 1205 \\
\hline 30 & 246.4 & 105.6 & 176 & 676 & 1205 \\
\hline
\end{tabular}

The experiment includes four series of samples. According to ACI 548.2R-93 [10] for the maximum aggregate size of $12.7 \mathrm{~mm}$, the percent by weight of the cement (sulfur) has been used as 0, 10, 20 and 30\% (Table 1). From each batch three $10 \times 10 \times 10 \mathrm{~cm}$ cubic samples were casted. The samples were dried in the ambient temperature. After drying its bulk density ( $\rho b)$, watertightness (w), absorptivity (a) and total porosity (Pt) was taken [11]. 


\section{Results}

The concrete with sulfur addition has higher bulk density than control probe. Mixes with 20 and $30 \mathrm{wt} \%$ of sulphur addition have similar values of density. The higher bulk density indicates on higher watertightness and lower values of absorptivity and total porosity. The concrete with $30 \mathrm{wt} \%$ of sulphur admixture proved the most watertight and least porous (Table 2).

Table 2. Average values of bulk density $(\rho \mathrm{b})$, watertightness $(\mathrm{w})$, absorptivity $(\mathrm{a})$, and total porosity $\left(\mathrm{P}_{\mathrm{t}}\right)$ for all of the samples.

\begin{tabular}{|c|c|c|c|c|}
\hline Reference & $\mathbf{\rho b}$ & $\mathbf{w}$ & $\mathbf{a}$ & $\mathbf{P}_{\mathbf{t}}$ \\
\hline 0 & 2.11 & 69.8 & 10.3 & 30.2 \\
\hline 10 & 2.30 & 93.9 & 1.12 & 6.1 \\
\hline 20 & 2.41 & 95.3 & 0.36 & 4.7 \\
\hline 30 & 2.49 & 96.8 & 0.1 & 3.2 \\
\hline
\end{tabular}

\section{Summary}

Obtained research was a successful experiment, which could develop the process of depth impregantion of concrete surfaces. The sulfur concrete surfaces were more resistant to water absorption than concrete made from Protland cement. Presented test results confirmed possibilities of sulfur concrete usage as a surface protector form for corrosive environment.

\section{Conclusions}

It was found that replacing part of the cement with waste sulfur in technical concrete changes soma of its physical properties. This change is hardly dependent on the concentration of sulfur. Based on the test result presented in the paper, the following general conclusions could be formulated:
- The obtained results showed that the physical properties of concrete are influenced with sulfur admixture. The watertightness of $10 \mathrm{wt} \%$ sulfur addition is similiar to Portland cement. For other mixtures the watertightness was higher than concrete without sulfur admixtures ;

- The absorptivity of concrete containing 20 and $30 \mathrm{wt} \%$ of sulfur were lower than a reference probe;

- The sulfur admixture decreased the total porosity.

\section{References}

1. E. Kwon, J. Ahn, B. Cho, D. Park., Constr. Build. Mater. 83, 174-180 (2015)

2. E. Güneyisi, M. Gesoglu, N. Naji, S. İpek. Arch. Civ. Mech. Eng. 16-1, 9-19 (2016)

3. M.Y. Cheng, M.T. Cao., J. Civ. Eng. Manag. 22-5, 711-720 (2016)

4. M. Książek. Constr. Build. Mater., 68, 558-564 (2014)

5. M. Książek. Engineering 62(62C), 137-142 (2014)

6. M. Książek. Engineering, 58(58C), 378-385 (2013)

7. M. Książek. Experimental research on the surface protection of concrete by polymer sulfur composite, Mag. Concrete Res. 64(10), 945-955 (2012)

8. EN 197-1:2011. Cement. Composition, specifications and conformity criteria for common cements

9. ASTM D 3515. Standard Specification for HotMixed, Hot-Laid Bituminous Paving Mixtures

10. ACI 548.2R-93. Guide for Mixing and Placing Sulfur Concrete in Construction

11. EN 1936:2010. Natural stone test methods. Determination of real density and apparent density, and of total and open porosity 